\title{
Inhibin- $\alpha$ gene mutations and mRNA levels in human lymphoid and myeloid leukemia cells
}

\author{
YOUNG IL KIM ${ }^{1}$, SEUNG-WON PARK ${ }^{2}$, HYE SHIN KWON ${ }^{3}$, HYUNG-SEOK YANG ${ }^{4}$, \\ SUN YOUNG CHO ${ }^{4}$, YOUNG JIN KIM ${ }^{4}$ and HEE JOO LEE ${ }^{4}$
}

\author{
${ }^{1}$ Medical Science Research Institute, Kyung Hee University Medical Center, Seoul 02447; ${ }^{2}$ Department of Biotechnology, \\ Catholic University of Daegu, Daegu 38430; ${ }^{3}$ Department of Biomedical Science, Graduate School and \\ ${ }^{4}$ Department of Laboratory Medicine, School of Medicine, Kyung Hee University, Seoul 02447, Republic of Korea
}

Received August 21, 2016; Accepted December 2, 2016

DOI: $10.3892 /$ ijo.2017.3895

\begin{abstract}
The inhibin- $\alpha$ gene was identified as a tumor suppressor gene in the gonads and adrenal glands by functional studies using knockout mice. Methylation of $\mathrm{CpG}$ sites within the regulatory regions of tumor suppressor gene is frequently associated with their transcriptional silencing. We investigated epigenetic modifications, changes in loss of heterozygosity ( $\mathrm{LOH}$ ), and mutation of the inhibin- $\alpha$ gene, and regulation of transcriptional expression in response to inhibitors of DNA methylation (5-aza-2'-deoxycytidine, 5-AzaC) in human lymphoid (Jurkat, Molt-4, Raji, and IM-9) and myeloid (HL-60, Kasumi-1, and K562) leukemia cells. The inhibin- $\alpha$ promoter was hypermethylated in lymphoid (Molt-4 and Raji) and myeloid (HL-60 and Kasumi-1) leukemia cells. Inhibin- $\alpha$ gene mutations differed significantly between lymphoid (heterozygote) and myeloid (homozygote) leukemia cells. LOH in the inhibin- $\alpha$ gene was detected in lymphoid and myeloid leukemia cells, with the exception of Jurkat cells. Treatment with 5-AzaC, a demethylating agent, resulted in increased inhibin- $\alpha$ mRNA and protein levels in most of the cell lines. Also, 5-AzaC treatment inhibited cell proliferation and induced apoptosis. Taken together, our results reveal that the inhibin- $\alpha$ gene is transcriptionally silenced in human leukemia cells and that reactivation is suppressed by a demethylating agent. In addition, mutations in, and expression levels of, the inhibin- $\alpha$ gene differed between human lymphoid and myeloid leukemia cells.
\end{abstract}

\section{Introduction}

Methylation of islands has been shown to inhibit transcription directly or stabilize chromatin in a conformation that

Correspondence to: Dr Hee Joo Lee, Department of Laboratory Medicine, School of Medicine, Kyung Hee University, 23 Kyung Hee Dae-ro, Dongdaemun-gu, Seoul 02447, Republic of Korea

E-mail: leehejo@khmc.or.kr

Key words: inhibin- $\alpha$, hypermethylation, loss of heterozygosity, human leukemia cells prevents transcription (1). Hypermethylation of $\mathrm{CpG}$ islands is an important epigenetic mechanism for silencing the transcription of many genes (2). DNA methylation inhibits gene transcription by affecting the chromatin structure, in particular via the protein complexes comprising methyl-binding domains, transcriptional corepressors, and histone deacetylase in hypermethylated regions of DNA (3-5). In hematopoietic development, this was first demonstrated for erythropoiesis, and later also for lymphoid and myeloid differentiation (6-9). Aberrant methylation of tumor-suppressor and growth-regulatory genes has been reported as the most frequent alteration in both hematologic neoplasms and solid tumors (10). Promoter methylation is an increasingly recognized mechanism of transcriptional silencing in human cancer. Downregulated expression of target genes results from single transitional changes in these important regulatory sequences. It has been demonstrated that promoter methylation can be induced by viral agents or by recruitment of the methyl-transferase enzymatic machinery $(11,12)$.

Inhibins and activins, members of the transforming growth factor- $\beta$ (TGF- $\beta$ ) superfamily, are polypeptides that were originally isolated from ovarian fluid, based on their effect on pituitary follicle-stimulating hormone (FSH) production and secretion. Inhibins are heterodimers that are composed of a common $\alpha$ subunit and one of two homologous $\beta$ subunits $(\beta \mathrm{A}$ and $\beta \mathrm{B})(13,14)$. More recently, both inhibins and activins have been implicated in endocrine-related cancers (15). The inhibin- $\alpha$ gene was identified as a tumor suppressor gene in the gonads and adrenal glands by functional studies using knockout mice $(16,17)$. This has raised the question of whether it plays a broader role as a tumor suppressor outside the reproductive axis. Furthermore, hypermethylation of the inhibin- $\alpha$ gene promoter and loss of heterozygosity (LOH) at 2q32-36, the chromosome region harboring the inhibin- $\alpha$ gene, has been reported in prostate carcinoma and gastric cancer $(18,19)$. Moreover, there was a positive correlation between loss of inhibin expression and malignancy of these human prostate carcinoma cells (20). Hypermethylation of the inhibin- $\alpha$ promoter and $\mathrm{LOH}$ are frequently associated with silencing or loss of expression of tumor suppressor genes, and the effects of deletions involving the 2q33-36 regions in human leukemia cells are unclear. Recently many studies have been made regu- 
lating promoter methylation which is a useful biomarker for the diagnosis of cancer patients $(21,22)$.

We investigated the epigenetic modifications, changes in $\mathrm{LOH}$ and mutations of the inhibin- $\alpha$ gene, and regulation of transcriptional expression by inhibitors of DNA methylation (5-aza-2'-deoxycytidine, 5-AzaC) in human lymphoid and myeloid leukemia cells.

\section{Materials and methods}

Cell culture. Lymphoid (Jurkat, Molt-4, IM-9, and Raji) and myeloid (HL-60, Kasumi-1, and K562) human leukemia cell lines were purchased from the American Tissue Culture Collection (ATCC, Rockville, MD, USA). Cells were cultured in RPMI-1640 medium (Gibco, Grand Island, NY, USA) containing $10 \%$ fetal bovine serum (FBS), $100 \mathrm{U} / \mathrm{ml}$ penicillin and $100 \mu \mathrm{g} / \mathrm{ml}$ streptomycin at $37^{\circ} \mathrm{C}$ in a humidified atmosphere of $5 \% \mathrm{CO}_{2}$ in $95 \%$ air.

Bisulfite modification. The methylation status of the promoter $\mathrm{CpG}$ islands of the inhibin- $\alpha$ subunit gene was analyzed by methylation specific PCR (MSP) using sodium-bisulfiteconverted DNA (23). Genomic DNA was extracted using the Wizard Genomic DNA purification kit (Promega, Madison, WI, USA). DNA $(2 \mu \mathrm{g})$ in a volume of a $50 \mu \mathrm{l}$ was denatured with $\mathrm{NaOH}$ (final concentration, $0.2 \mathrm{M}$ ) and incubated at $37^{\circ} \mathrm{C}$ for $15 \mathrm{~min}$. Then, $30 \mu \mathrm{l}$ of $10 \mathrm{mM}$ hydroquinone and $520 \mu \mathrm{l}$ of $3 \mathrm{M}$ sodium bisulfite (Sigma-Aldrich, St. Louis, MO, USA) at $\mathrm{pH}$ 5.0, both freshly prepared, were added and mixed, and samples were incubated under mineral oil at $55^{\circ} \mathrm{C}$ for $16 \mathrm{~h}$. DNA was then desalted using the Wizard DNA Clean-Up System (Promega), desulfonated by addition of $\mathrm{NaOH}$ (final concentration, $0.3 \mathrm{M}$ ), and incubated at $37^{\circ} \mathrm{C}$ for $15 \mathrm{~min}$. The solution was neutralized by addition of ammonium acetate (final concentration, 3.0 M), and the DNA was ethanolprecipitated, dried, re-suspended in $20 \mu \mathrm{l}$ of water and used immediately or stored at $-20^{\circ} \mathrm{C}$.

Determination of methylation status. Methylation was assessed by PCR and sequence analysis of bisulfite-treated DNA. The bisulfite reaction converted unmethylated cytosines to uracils, whereas methylated cytosines were unchanged. The inhibin- $\alpha$ subunit 5'-UTR region was amplified by nested PCR using primers for the bisulfite-converted sequence (18). Primers 1 (5'-GATAAGAGTTTAGATTGGTTTTATTGGTT-3') and 2 (5'-ACACCATAACTCACCTAACCCTACTAATAA-3') were used for the first round of PCR, and primers 3 (5'-ACC CCTTCTACCAAAATCTACCCAAAA-3') and 4 (5'-GAAG GTGTTGTATGTTTGTATGTGTGAGTT-3') were used for the second round. The first round of PCR was performed in $25 \mu \mathrm{l}$ reactions with $2 \mu \mathrm{l}$ of bisulfite-converted DNA, 1X PCR buffer [10 mM Tris (pH 8.3), $50 \mathrm{mM} \mathrm{KCl,} 1.5 \mathrm{mM} \mathrm{MgCl}_{2}$ ], $200 \mu \mathrm{M}$ dNTPs, $10 \mathrm{pmol}$ of primers 1 and 2, and $1 \mathrm{U}$ AmpliTaq Gold DNA polymerase (Roche, Applied Biosystems, Foster City, CA, USA). PCR cycles consisted of $95^{\circ} \mathrm{C}$ for $15 \mathrm{~min}$, followed by 5 cycles of $95^{\circ} \mathrm{C}$ for $1 \mathrm{~min}, 50^{\circ} \mathrm{C}$ for $2 \mathrm{~min}$, and $72^{\circ} \mathrm{C}$ for $3 \mathrm{~min}$, and then 30 cycles of $95^{\circ} \mathrm{C}$ for $1 \mathrm{~min}, 55^{\circ} \mathrm{C}$ for $2 \mathrm{~min}$, and $72^{\circ} \mathrm{C}$ for $2 \mathrm{~min}$, with a final incubation step of $72^{\circ} \mathrm{C}$ for $10 \mathrm{~min}$. A sample of $2 \mu \mathrm{l}$ from the first PCR was amplified in a $25-\mu 1$ reaction as above, except that primers 3 and 4 were used. PCR cycling conditions were as for the first reaction, with the exception that the annealing temperature was increased to $60^{\circ} \mathrm{C}$. PCR products were gel-purified, ligated into the pCR 2.1 vector, and cloned using the TOPO TA Cloning kit according to the manufacturer's instructions (Invitrogen, Carlsbad, CA, USA). For each PCR, 10 clones were sequenced and methylation at each of the seven $\mathrm{CpG}$ sites was determined. Overall percentage methylation of each sample was determined as the mean of the percentage methylation at the seven individual CpG sites.

DNA analysis. DNA was isolated from cultured cells using standard methods. Two regions of the inhibin- $\alpha$ subunit gene were amplified from genomic DNA by PCR using specific oligonucleotide primers (24). The first 240-bp region (fragment A), which includes 140 bp of the 5'-UTR and $100 \mathrm{bp}$ of exon 1, was amplified using the primers AF (5'-GACTGGGGA AGACTGGATGA-3') and AR (5'-TCACCTTGGCCAG AACAAGT-3'). The second 396-bp region (fragment B), which comprises part of exon 2, was amplified using the primers $\mathrm{BF}$ (AGCAGCCTCCAATAGCTCTG-3') and BR (5'-AGCTCCT GGAAGGAGATGTTC-3'). Genomic DNA (200 ng) was amplified in a 50- $\mu 1$ volume reaction containing $1 \mathrm{X}$ PCR buffer, $2 \mathrm{mM} \mathrm{MgCl} 2,2.5 \%$ DMSO, $0.2 \mathrm{mM}$ dNTP, 20 pmol of each specific primer and $1.5 \mathrm{U}$ AmpliTaq Gold DNA polymerase. The amplification conditions were as follows: 35 cycles comprising an initial denaturation at $95^{\circ} \mathrm{C}$ for $14 \mathrm{~min}$, then denaturation at $95^{\circ} \mathrm{C}$ for $40 \mathrm{sec}$, annealing at $57^{\circ} \mathrm{C}$ for $30 \mathrm{sec}$, and extension at $72^{\circ} \mathrm{C}$ for $1 \mathrm{~min}$, followed by a final extension at $72^{\circ} \mathrm{C}$ for $7 \mathrm{~min}$. Polymorphism $-16 \mathrm{C}>\mathrm{T}$ in $5^{\prime}$-UTR was screened in the samples by restriction enzyme analysis using SpeI (New England Biolabs, Ipswich, MA, USA). Briefly, fragment A was amplified by PCR and $5 \mu \mathrm{l}$ of purified PCR product was digested overnight at $37^{\circ} \mathrm{C}$ with $5 \mathrm{U}$ of SpeI, electrophoresed in $8 \%$ polyacrylamide gels, stained with ethidium bromide and photographed. The presence of the 240-bp fragment indicated a variant homozygous for C, whereas the presence of two fragments of $120 \mathrm{bp}$ corresponded to a variant homozygous for T. Substitution $769 \mathrm{G}>\mathrm{A}$ of exon 2 was analyzed by digestion of fragment B with appropriate restriction enzymes. Five microliters of purified PCR product was digested overnight at $37^{\circ} \mathrm{C}$ with $5 \mathrm{U}$ of $\mathrm{BsrFI}$ and analyzed as described above. The restriction site, which renders two fragments of 340 and $56 \mathrm{bp}$, is abolished in the mutated allele. In addition, $5 \mu 1$ of purified PCR product was digested overnight at $37^{\circ} \mathrm{C}$ with $5 \mathrm{U}$ of $\mathrm{Fnu} 4 \mathrm{HI}$, electrophoresed in $15 \%$ polyacrylamide gels, stained with ethidium bromide and visualized by image analysis. The 396-bp fragment yields four fragments of 153, 107, 51 and $25 \mathrm{bp}$, among others of lower molecular weight, in the wild-type allele, whereas the allele with substitution $769 \mathrm{G}>$ A yields four fragments of 153, 107, 76 , and $51 \mathrm{bp}$, among others of lower molecular weight.

LOH analysis. $\mathrm{LOH}$ was determined using microsatellite markers on 2q32-q33 (D2S389) and 2q33-q36 (D2S128), as described previously (18). The primers used were D2S389 (5'-TAAAGCCTAGTGGAAGATCATC-3', 5'-GCTGAGTT AACAGTTATCAACAATT-3') and D2S128 (5'-AAACTGAG ATTTGTCTAAGGGG-3', 5'-AGCCAGGAATTTTTGCT ATT-3'). PCR was performed in $20 \mu \mathrm{l}$ reactions consisting of 
$200 \mathrm{ng}$ of DNA, 1X PCR buffer, $0.2 \mathrm{mM}$ dNTPs, $10 \mathrm{pmol}$ of each primer, and $1 \mathrm{U}$ AmpliTaq Gold DNA polymerase. The amplification conditions were as follows: 35 cycles of an initial denaturation at $95^{\circ} \mathrm{C}$ for $14 \mathrm{~min}$, a second denaturation at $95^{\circ} \mathrm{C}$ for $1 \mathrm{~min}$, annealing at $55^{\circ} \mathrm{C}$ for $1 \mathrm{~min}$, and extension at $72^{\circ} \mathrm{C}$ for $1 \mathrm{~min}$, followed by a final extension at $72^{\circ} \mathrm{C}$ for $10 \mathrm{~min}$. Then, $10 \mu \mathrm{l}$ of PCR products was mixed with $10 \mu \mathrm{l}$ of stop solution containing 95\% formamide, $10 \mathrm{mM} \mathrm{NaOH}, 0.25 \%$ bromophenol blue, and $0.25 \%$ xylene cyanol FF. The mixture was denatured at $95^{\circ} \mathrm{C}$ for $5 \mathrm{~min}$, placed on ice for $5 \mathrm{~min}$, electrophoresed in $12 \%$ polyacrylamide gels containing $10 \%$ glycerol with $1 \mathrm{X}$ TBE buffer, and stained with ethidium bromide.

5-Aza-2'-deoxycytidine treatment. Cells were seeded at a density of $5 \times 10^{5} / 100 \mathrm{~mm}$ dish, allowed to attach for $24 \mathrm{~h}$ and then treated with various concentration of 5-aza-2'-deoxycytidine (5-AzaC, Sigma) for 5 days. The medium and drug were replaced every 2 days. At the end of the treatment period, the medium was removed and the cell pellets were used for analysis.

RNA extraction and real-time PCR. Total RNA was extracted from cultured cells using the TRIzol Reagent kit following the manufacturer's protocol (Invitrogen). First-strand cDNA was synthesized from $1 \mu \mathrm{g}$ of DNase-treated RNA using a reverse transcription system (Promega) according to the manufacturer's protocol with random hexamers. PCR was performed with $2 \mu \mathrm{l}$ cDNA in a $25-\mu 1$ reaction mixture of 1X PCR buffer, $0.2 \mathrm{mM}$ of each dNTP, 10 pmol of primers for inhibin- $\alpha$ (5'-AGGAAGAGGAGGATGTCTCC-3' and 5'-GAGTAACCTCCATCCCGAGGT-3'; 823 bp), betaglycan (5'-ACATGGATAAGAAGCGATTCAGC-3' and 5'-AAC GCAATGCCCATCACGGTTAG-3', $331 \mathrm{bp}$ ), and $\beta$-actin (5'-CTTCTACAATGAGCTGCGTG-3' and 5'-TCATGAG GTAGTCAGTCAGG-3'; 305 bp), and 1 U AmpliTaq Gold DNA polymerase. The reactions were carried out in a thermal cycler with an initial denaturation step at $95^{\circ} \mathrm{C}$ for $14 \mathrm{~min}$, followed by 35 cycles ( 25 cycle for $\beta$-actin) of denaturation at $95^{\circ} \mathrm{C}$ for $1 \mathrm{~min}$, primer annealing at $50^{\circ} \mathrm{C}$ (inhibin- $\alpha$ ) to $55^{\circ} \mathrm{C}$ ( $\beta$-actin) for $1 \mathrm{~min}$, and a final extension at $72^{\circ} \mathrm{C}$ for $1 \mathrm{~min}$. The reaction was terminated at $72^{\circ} \mathrm{C}$ for $10 \mathrm{~min}$; samples were stored at $4^{\circ} \mathrm{C}$. Ten microliters of PCR products were separated by electrophoresis in a $2 \%$ agarose gel containing ethidium bromide $(0.5 \mu \mathrm{g} / \mathrm{ml})$ and visualized by image analysis (Gel Doc 1000 Gel Documentation System; Bio-Rad, Hercules, CA, USA). Real-time PCR was performed on a StepOnePlus Real-Time PCR System with Power SYBR Green PCR Master Mix (Applied Biosystems). The gene-specific primer sequences were: inhibin- $\alpha$, 5'-CTCGGATGGAGGTTACTCTTTCAA-3' and 5'-GAAGACCCCCCACCCTTAGA-3' (88 bp); betaglycan, 5'-CAAAGCAGCAGAAGGGTGTGT-3' and 5'-GGTGATTA GCTCGATGATGTGTACTT-3' (73 bp); and $\beta$-actin, $5^{\prime}$-GCG AGAAGATGACCCAGATC-3' and 5'-GGATAGCACAGCCT GGATAG-3' (77 bp). PCR was performed with $1 \mu 1$ of cDNA in a 20- $\mu \mathrm{l}$ reaction mixture containing $10 \mu \mathrm{l}$ of Power SYBR Green PCR Master Mix, $2 \mu 1$ of primers, and $7 \mu l$ of PCR-grade water. The reaction conditions were denaturation at $95^{\circ} \mathrm{C}$ for $10 \mathrm{~min}$, followed by 40 cycles of $95^{\circ} \mathrm{C}$ for $15 \mathrm{sec}$ and $60^{\circ} \mathrm{C}$ for $1 \mathrm{~min}$. The crossing points of the target genes with $\beta$-actin were calculated using the formula $2^{\text {-(target gene- } \beta \text {-actin) }}$, and relative amounts were quantified.

FITC-flow cytometric analysis of inhibin- $\alpha$ protein. Cultured cells were detached with $0.05 \%$ trypsin-EDTA solution. After washing with cold PBS, cells were incubated with a 1:50 dilution of anti-inhibin- $\alpha$ goat polyclonal antibody (Santa Cruz Biotechnology, Santa Cruz, CA, USA) or normal goat serum as a negative control for $30 \mathrm{~min}$ at $4^{\circ} \mathrm{C}$. After washing three times with cold PBS, cells were stained with a fluorescein isothiocyanate (FITC)-labeled donkey antibody (1:50 dilution) to rabbit immunoglobulin for $30 \mathrm{~min}$ at $4^{\circ} \mathrm{C}$. Washing was repeated in the same manner and cell-surface immunofluorescence was analyzed using a FACSCalibur instrument together with CellQuest software (Becton-Dickinson, San Jose, CA, USA).

Determination of cell doubling time. Cells were treated with $5 \mu \mathrm{M} 5$-AzaC for 5 days and washed with PBS. Cells were seeded at $2 \times 10^{4} / \mathrm{ml}$ in 12 -well plates containing culture medium, and cell number/dish was determined by trypan blue assay daily for 5 consecutive days. Untreated cells were analyzed under similar conditions as a control. The average cell number from two plates was determined, and the mean cell numbers were plotted to calculate the doubling times. The cell population doubling time was calibrated using the Kuchler formula (25).

Cell cycle analysis. Cells $\left(5 \times 10^{5}\right)$ were treated with $5 \mu \mathrm{M}$ 5-AzaC for 5 days. At the end of the treatment period, cells were harvested, washed with PBS, fixed with $70 \%$ ethanol for $1 \mathrm{~h}$, treated with RNAsin $(20 \mu \mathrm{g} / \mathrm{ml})$ at $37^{\circ} \mathrm{C}$ for $1 \mathrm{~h}$, and stained with propidium iodide ( $50 \mu \mathrm{g} / \mathrm{ml}$; Sigma). DNA content at each cell cycle stage was analyzed using a FACSCalibur instrument together with CellQuest software (Becton-Dickinson).

Statistical analysis. Values are expressed as means \pm SD. Student's t-test was used to evaluate differences among the samples. Statistical analyses were performed using GraphPad Prism 5 software (GraphPad Software Inc., San Diego, CA, USA). ${ }^{*} \mathrm{P}<0.05$ and ${ }^{* * *} \mathrm{P}<0.01$ were considered to indicate statistical significance.

\section{Results}

Methylation status of the inhibin- $\alpha$ gene promoter in human leukemia cells. Methylation at the seven $\mathrm{CpG}$ sites, in the 135 bp region from -149 to -284 of the ATG site in the human inhibin- $\alpha$ gene promoter, was investigated by bisulfite genomic sequencing (Fig. 1A). Molt-4, Raji, HL-60, and Kasumi-1 cells showed marked hypermethylation of the inhibin- $\alpha$ subunit gene promoter; in contrast, Jurkat cells exhibited hypomethylation. This region was almost unmethylated in IM-9 and K562 cells (Fig. 1B).

Mutations of the inhibin- $\alpha$ gene in human leukemia cells. A mutation study of the inhibin- $\alpha$ gene in human leukemia cells was carried out. The PCR product (fragment A) including nucleotide -16 was digested with SpeI (Fig. 2A). Polymorphisms were identified within the 5'-UTR and exon 1 


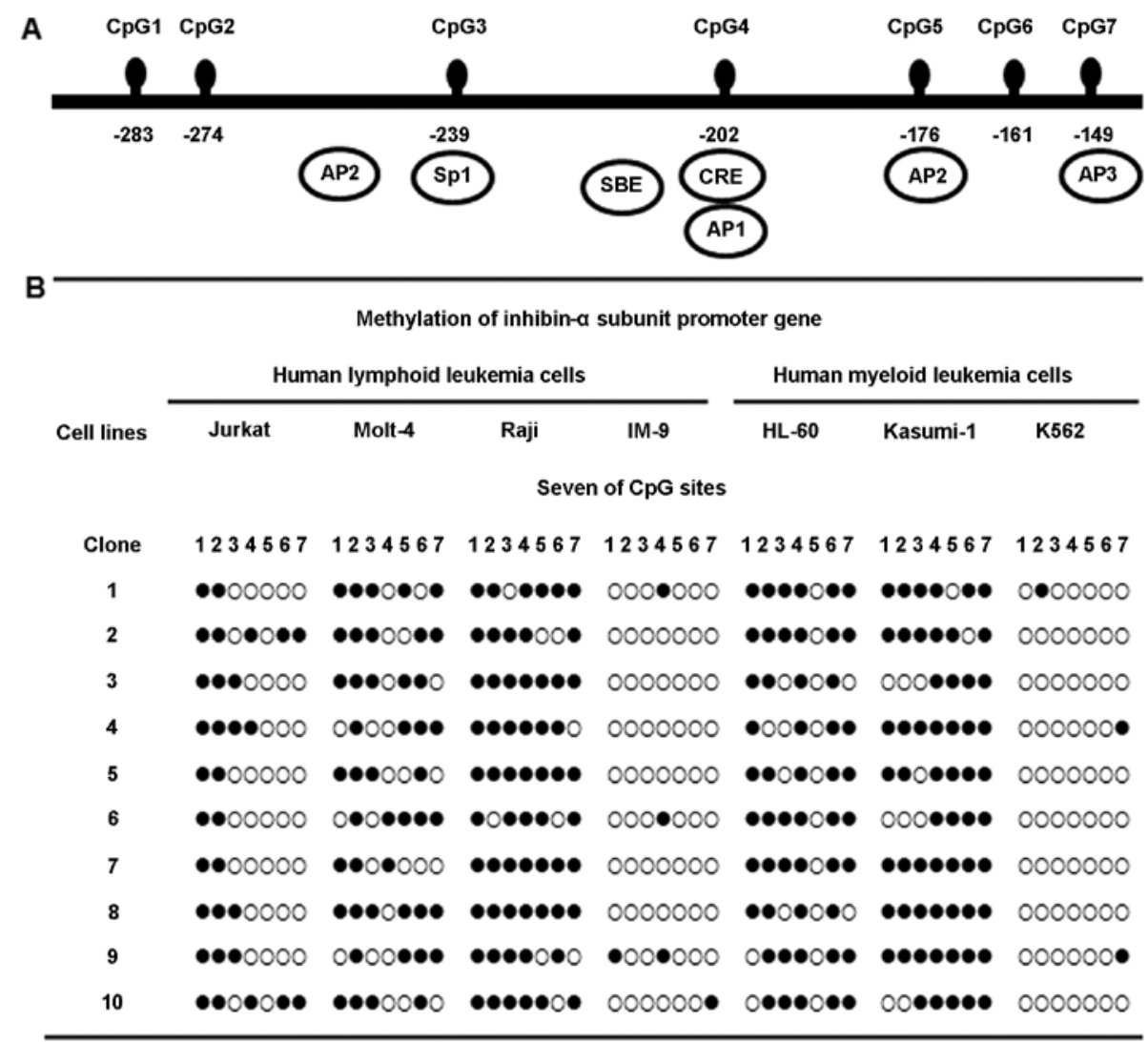

Figure 1. Analysis of the methylation status of the inhibin- $\alpha$ promoter region in human leukemia cells. (A) Map of CpG sites in the inhibin- $\alpha$ promoter in the 135-bp region from -149 to - 284 of the ATG start site (18). (B) Methylation profile of the inhibin- $\alpha$ promoter region in human leukemia cells. Methylation levels were determined by sequencing of 10 independent clones derived from amplified bisulfite-treated DNA isolated from human leukemia cells. Unmethylated and methylated $\mathrm{CpG}$ dinucleotides are represented by open $(0)$ and closed circles $(\bullet)$, respectively.

and used to divide the cell lines into the following two groups: i) CC genotype (Molt-4, Raji, and HL-60 cells) and ii) CT genotype (Jurkat and IM-9 cells) + TT genotype (Kasumi-1 and K562 cells). Interestingly, inhibin- $\alpha$ gene mutation patterns differed between lymphoid leukemia cells (CT, heterozygote) and myeloid leukemia cells (TT, homozygote). Substitution $769 \mathrm{G}>\mathrm{A}$ of exon 2 in human leukemia cells was analyzed by restriction enzyme digestion. A PCR product comprising nucleotide 769, fragment B, was digested with BsrFI (Fig. 2B) and/or Fnu4HI (Fig. 2C). The single base change at $769 \mathrm{G}>\mathrm{A}$ of exon 2 was not found in the seven human leukemia cell lines.

LOH at $2 q$ in human leukemia cells. $\mathrm{LOH}$ was determined by PCR of genomic DNA. Analysis of the $2 \mathrm{q}$ chromosome arm revealed that $\mathrm{LOH}$ with at least one microsatellite marker occurred at 2q32-36 in Jurkat, Molt-4, Raji, IM-9, HL-60, Kasumi-1, and K562 cells (Fig. 2D). LOH at 2q32-33 was observed in human lymphoid (Molt-4, Raji, IM-9) and myeloid (K562) leukemia cells. LOH at 2q33-36 was observed in human myeloid (HL-60, Kasumi-1 and K562) leukemia cells, but not in human lymphoid leukemia cells. However, K562 cells exhibited LOH at both 2q32-33 and 2q33-36.

Effect of 5-AzaC treatment on inhibin- $\alpha$ and betaglycan $m R N A$ levels in human leukemia cells. Basal expression of inhibin- $\alpha$ mRNA was not detected in human leukemia cells, whereas betaglycan mRNA was expressed in the majority of cells (Fig. 3A). To evaluate the role of methylation in the inactivation of the inhibin- $\alpha$ gene promoter in human leukemia cells, a DNA methyltransferase inhibitor, 5-AzaC, was used. Human leukemia cells were treated with 2 and $5 \mu \mathrm{M}$ 5-AzaC, and inhibin- $\alpha$ and betaglycan mRNA levels were measured by real-time PCR (Fig. 3B). 5-AzaC treatment resulted in increased inhibin- $\alpha$ and betaglycan mRNA levels in all seven human leukemia cell lines. The magnitude of the increase in inhibin- $\alpha$ and betaglycan mRNA levels caused by 5 -AzaC treatment was greater in lymphoid than in myeloid leukemia cells.

Effect of 5-AzaC treatment on inhibin-a protein levels in human leukemia cells. Human leukemia cells were treated with $5 \mu \mathrm{M} 5$-AzaC, and inhibin- $\alpha$ subunit protein levels were measured by flow cytometry and FITC staining (Fig. 4). Treatment with 5-AzaC resulted in 11.3-32.3- and 14.0-27.2fold increases in inhibin- $\alpha$ protein levels in human lymphoid and myeloid leukemia cells. Fluorescence intensities after 5-AzaC treatment were higher in human lymphoid compared to myeloid leukemia cells.

Effect of 5-AzaC on the growth and doubling time of human leukemia cells. Cells exposed to $0.5,2$, and $5 \mu \mathrm{M} 5-\mathrm{AzaC}$ exhibited significant growth inhibition in a dose-dependent manner, and the population doubling time of human leukemia cells was increased by 1.3-2.6-fold (Table I). 


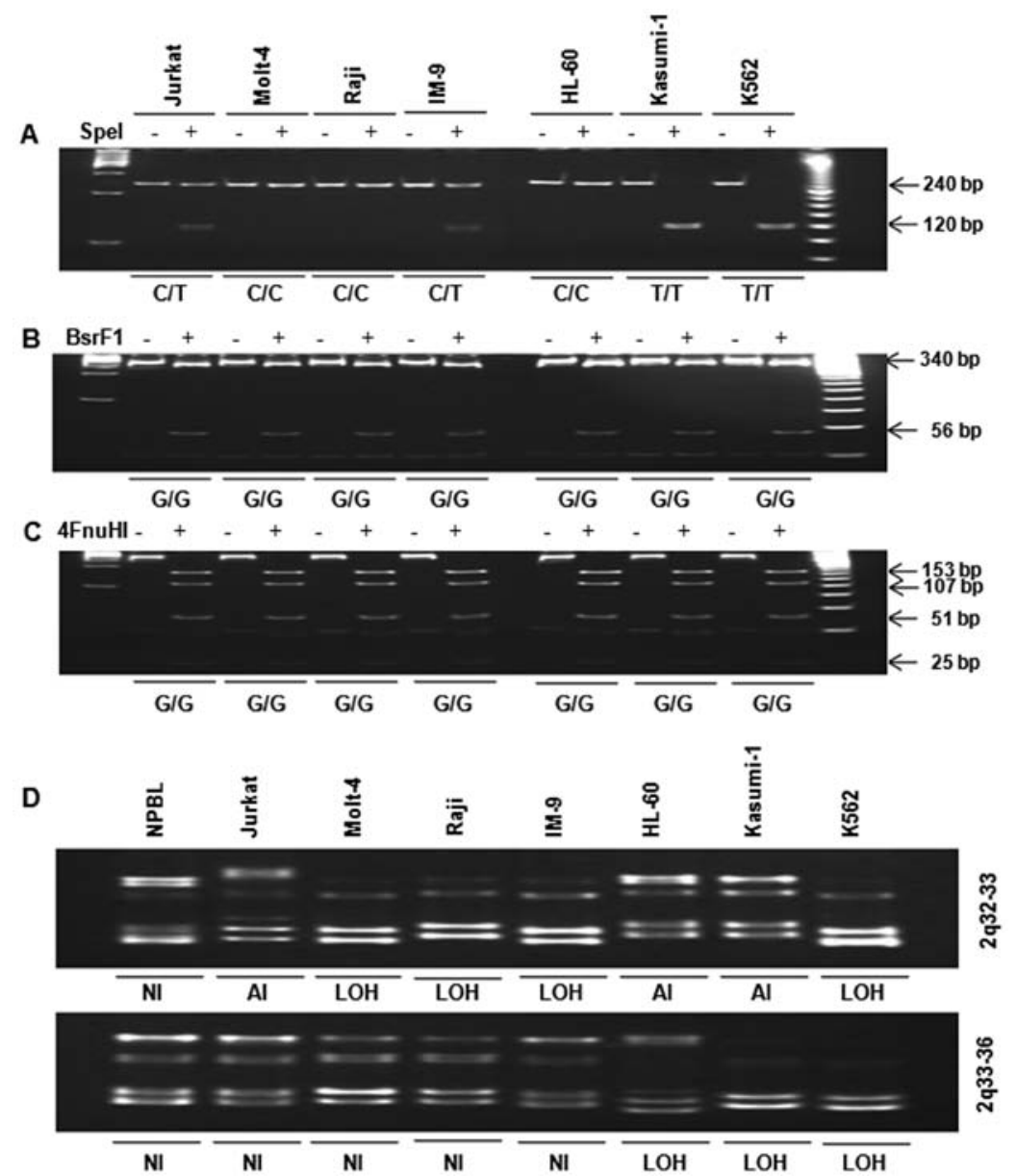

Figure 2. Analysis of polymorphism $-16 \mathrm{C}>\mathrm{T}$ in the 5 '-UTR and substitution $769 \mathrm{G}>\mathrm{A}$ in exon 2 by restriction enzyme digestion. (A) Fragment A was digested with SpeI. The presence of a 240-bp fragment indicated a variant homozygous for C, whereas the presence of two fragments of $120 \mathrm{bp}$ corresponded to a variant homozygous for T. (B) Fragment B was digested with BsrFI. Digestion of the 396-bp PCR product yielded two fragments of 340 and 56 bp in the wild-type allele (G), while the mutated allele remained uncleaved (A). (C) Fragment C was digested with FnuHI. Digestion of the 396-bp PCR product yielded four fragments of 153, 107, 51 and 25 bp (among others of lower molecular weight) in the wild-type allele, whereas the allele with the 769G $>$ A substitution yielded four fragments of 153, 107, 76 and $51 \mathrm{bp}$ (among others of lower molecular weight). PCR products were incubated overnight with (+E) and without (-E) restriction enzyme, separated in 8 and 15\% polyacrylamide gels, stained with ethidium bromide and photographed. LOH analysis of $2 \mathrm{q}$ in human leukemia cells. Genomic DNA was amplified by PCR for analysis of the 2q chromosomal region. PCR products were resolved in $12 \%$ polyacrylamide gels, stained with ethidium bromide and photographed. (D) 2q32-33 and 2q33-36. LOH was considered in the presence of a 50\% decrease in band intensity. NI, not informative; $\mathrm{LOH}$, loss of heterozygosity; AI, allelic imbalance.

Table I. Suppression by 5-AzaC of the growth of human leukemia cells.

\begin{tabular}{|c|c|c|c|c|c|c|c|}
\hline \multirow[b]{3}{*}{ Human leukemia cell lines } & \multicolumn{4}{|c|}{ Viability (\%) } & \multirow{2}{*}{\multicolumn{2}{|c|}{$\frac{\text { Doubling time }(\mathrm{h})}{5-\mathrm{AzaC}}$}} & \multirow[b]{3}{*}{ Fold growth suppression } \\
\hline & \multirow[b]{2}{*}{$0 \mu \mathrm{M}$} & \multicolumn{2}{|c|}{ 5-AzaC } & \multirow[b]{2}{*}{$5.0 \mu \mathrm{M}$} & & & \\
\hline & & $0.5 \mu \mathrm{M}$ & $2.0 \mu \mathrm{M}$ & & $0 \mu \mathrm{M}$ & $5.0 \mu \mathrm{M}$ & \\
\hline Jurkat & 100 & 28.8 & 28.8 & 28.1 & 20 & 50 & 2.5 \\
\hline Molt-4 & 100 & 42.1 & 40.6 & 39.5 & 36 & 68 & 1.9 \\
\hline Raji & 100 & 24.9 & 23.2 & 21.9 & 26 & 57 & 2.2 \\
\hline IM-9 & 100 & 38.6 & 35.6 & 33.2 & 34 & 55 & 1.6 \\
\hline HL-60 & 100 & 82.4 & 73.6 & 66.5 & 27 & 69 & 2.6 \\
\hline Kasumi-1 & 100 & 76.5 & 71.1 & 67.7 & 67 & 83 & 1.3 \\
\hline K562 & 100 & 88.2 & 82.8 & 81.1 & 47 & 84 & 1.8 \\
\hline
\end{tabular}

Cells $\left(5 \times 10^{5} / 100 \mathrm{~mm}\right.$ dish $)$ were treated with 5 -AzaC $(0,0.5,2.0$ and $5.0 \mu \mathrm{M})$ for 5 days. Viable cells were enumerated by trypan blue assay. At the end of the treatment period, the cells were seeded in 12-well plates at $5 \times 10^{4} / \mathrm{ml}$. Cell number/plate was determined by trypan blue assay daily for 5 consecutive days. Untreated cells were analyzed under similar conditions as a control. The average cell number from two plates was determined, and the mean cell numbers were plotted to calculatethe cell population doubling times. 
A

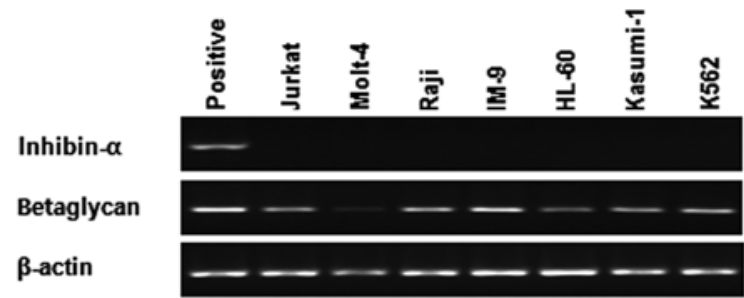

B

Human lymphoid leukemia cells

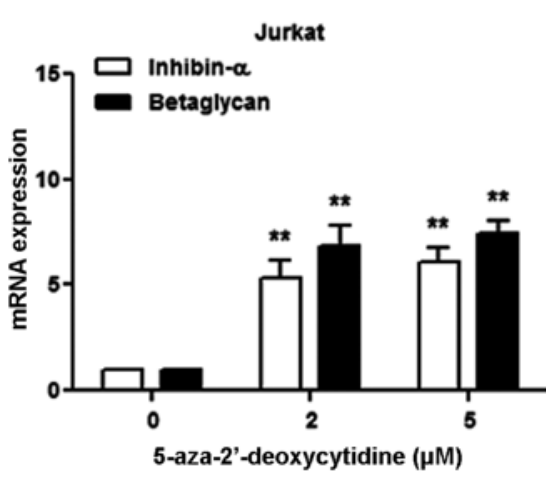

Molt-4

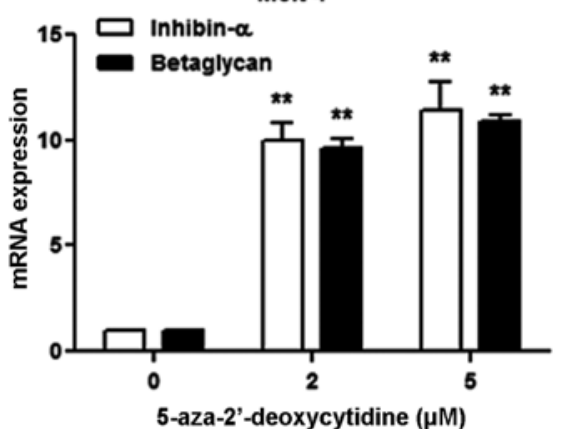

Raji

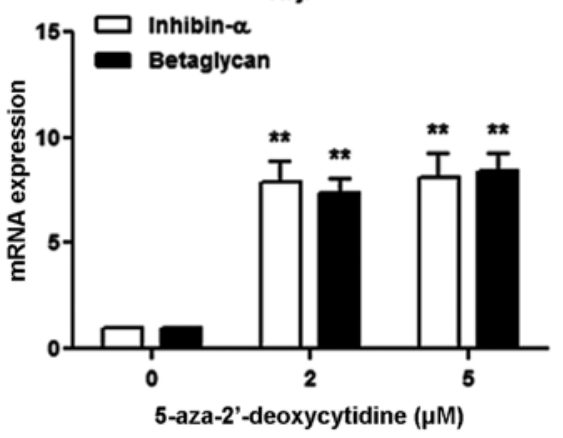

IM-9

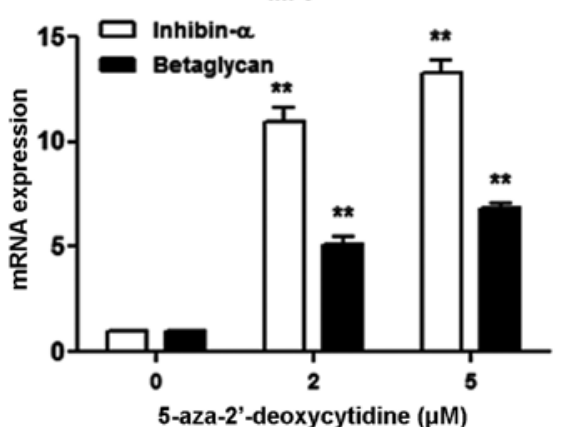

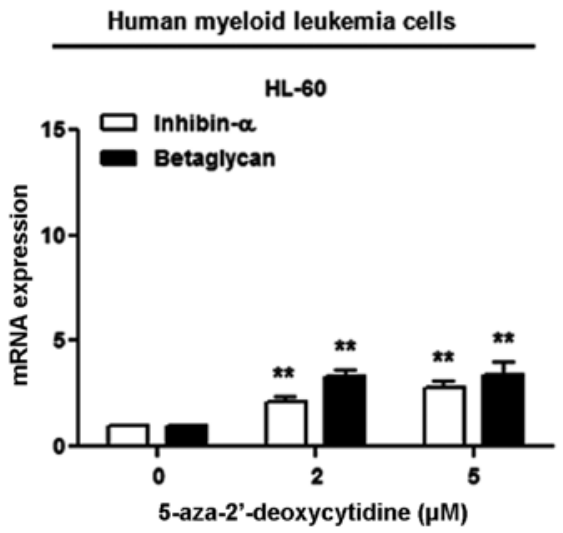

Kasumi-1

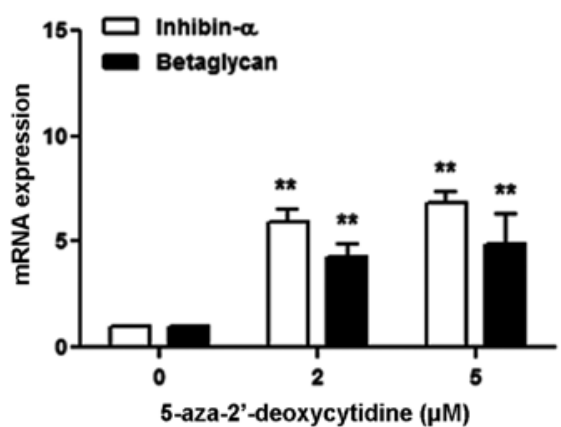

K562

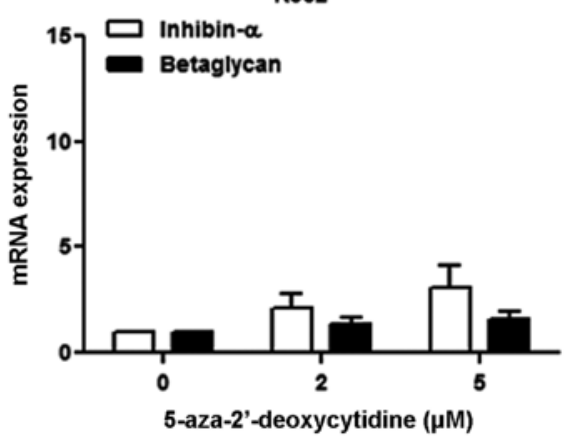

Figure 3. Effect of 5-AzaC treatment on inhibin- $\alpha$ and betaglycan mRNA levels in human leukemia cells. Cells were exposed to 2 or $5 \mu \mathrm{M} 5$-AzaC for 5 days. The medium and drug were replaced every 2 days. mRNA levels were measured by RT-PCR and real-time PCR. (A) PCR product was separated in a $2 \%$ agarose gel, stained with ethidium bromide and photographed. Positive control was used human gastric cancer cell line (SNU-668). (B) For real-time PCR, the crossing points of inhibin- $\alpha$ and betaglycan with $\beta$-actin were entered into the formula $2^{\text {-(target gene- } \beta \text {-actin) }}$, and relative amounts were quantified. The data are means \pm SD of three independent samples. ${ }^{*} \mathrm{P}<0.05$ and ${ }^{* *} \mathrm{P}<0.01$ compared with the control. 

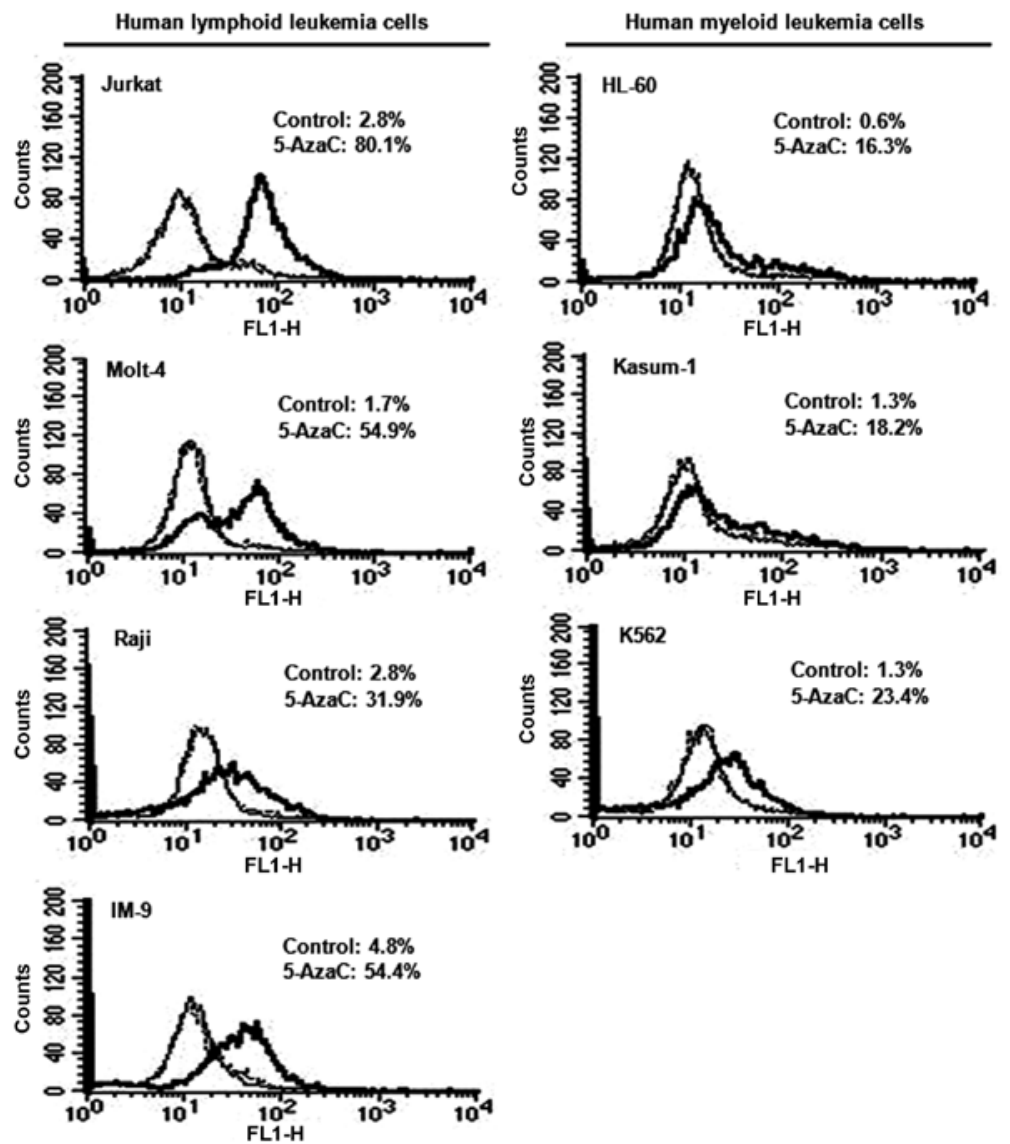

Figure 4. Inhibin- $\alpha$ protein levels in human leukemia cells. Cells were exposed to $5 \mu \mathrm{M} 5$-AzaC for 5 days. The medium and drug were replaced every 2 days, and inhibin- $\alpha$ protein was quantified by flow cytometry. The cells were incubated with an anti-inhibin- $\alpha$ polyclonal antibody and fluorescein isothiocyanate (FITC)-conjugated antibody. Diluted normal goat serum was used as a negative control primary antibody. Control cells, thin line; 5-AzaC-treated cells, thick line.

Effect of 5-AzaC on the cell cycle in human leukemia cells. The cell cycle profiles of human leukemia cells treated with $5 \mu \mathrm{M} 5$-AzaC were analyzed by flow cytometry (Fig. 5). The results suggested changes in the cell cycle and induction of apoptosis in 5-AzaC-treated cells. Treatment of Jurkat, Molt-4, Raji, IM-9, HL-60, Kasumi-1, and K562 cells with 5-AzaC resulted in a 1.7-36.2-fold increase in the proportion of apoptotic cells. Interestingly, human lymphoid leukemia cells exhibited a greater increase in the proportion of apoptotic cells than myeloid leukemia cells after treatment with 5-AzaC.

\section{Discussion}

Methylation of $\mathrm{CpG}$ sites within the regulatory regions of tumor-suppressor genes is a common aberration in human cancers that is frequently associated with gene silencing. In this study, the degree of methylation varied among the seven $\mathrm{CpG}$ sites in the inhibin- $\alpha$ gene promoter in four human lymphoid, and three human myeloid leukemia cells. Seven $\mathrm{CpG}$ sites were significantly hypermethylated in human lymphoid (Molt-4 and Raji) leukemia cells and human myeloid (HL-60 and Kasumi-1) leukemia cells, while lymphoid (Jurkat) leukemia cells exhibited hypomethylation. In contrast, this region was not methylated in lymphoid (IM-9) or myeloid (K562) leukemia cells. The inhibin- $\alpha$ subunit PC3 prostate cancer cell lines. The methylation pattern ranges from dense to sparse methylation, with CpG sites 0-3 being undermethylated in the DU145 and PC3 cell lines compared to the LNCaP cells (20). Our findings suggested that the methylation pattern at $\mathrm{CpG}$ sites did not differ significantly between human lymphoid and myeloid leukemia cells. Germline cells of chronic lymphocytic leukemia (CLL) patients with allele-specific expression (ASE) showed increased levels of DNA methylation in the promoter region (26).

Transcriptional silencing of tumor-suppressor genes can be caused by mutations. Two polymorphic sites were identified: $-16>\mathrm{T}$ in the $5-\mathrm{UTR}$ and $769 \mathrm{G}>\mathrm{A}$ in exon 2 . Mutation at the -16-bp site of the 5'-UTR was heterozygotic in lymphoid (Jurkat and IM-9) cells and homozygotic in myeloid (K562) cells. The -16-bp mutation in the 5'-UTR differed significantly between human lymphoid and myeloid leukemia cells, suggesting that human leukemia cells may be affected by the $-16>\mathrm{T}$ allele variant and supporting the concept that the 5'-UTR allele variant. In this study, Molt-4, Raji, IM-9, HL-60, and Kasumi-1 cells showed LOH at chromosome 2q32-36, but Jurkat cells did not. In contrast, K562 cells exhibited LOH at both 2q32-36 and 2q33-36. Changes at chromosome $2 q$ occur in prostate carcinoma and pediatric adrenocortical tumors (27-29). In bladder carcinoma and head-and-neck squamous cell carcinoma $(30,31), 2 q$ deletion is correlated with advanced disease and a poor prognosis. Taken together, our results 


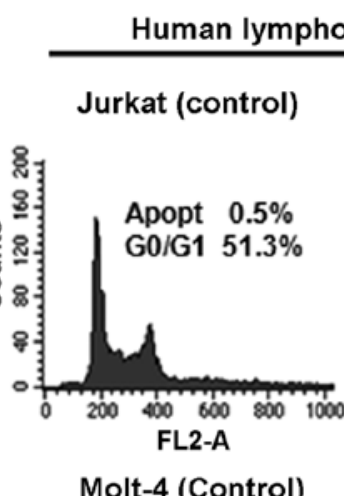

id leukemia cells

Jurkat (5-AzaC)

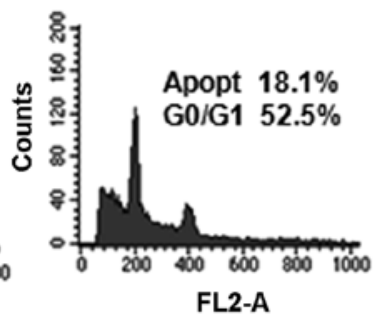

Molt-4 (5-AzaC)

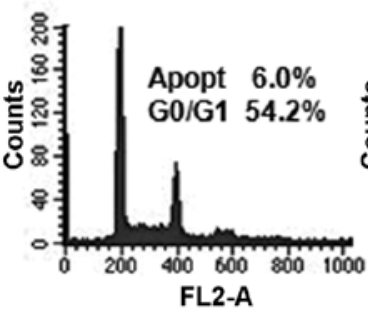

Raji (Control)

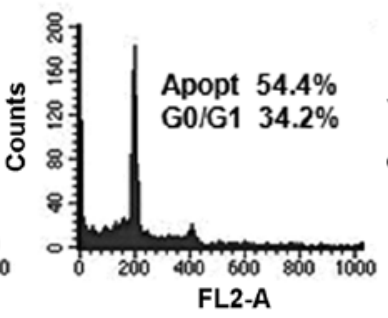

Raji (5-AzaC)
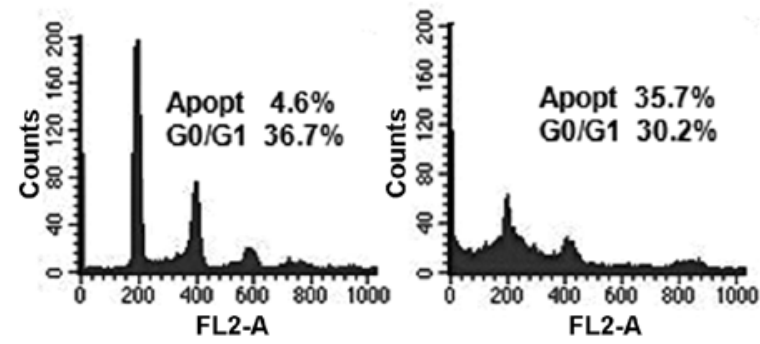

IM-9 (Control)

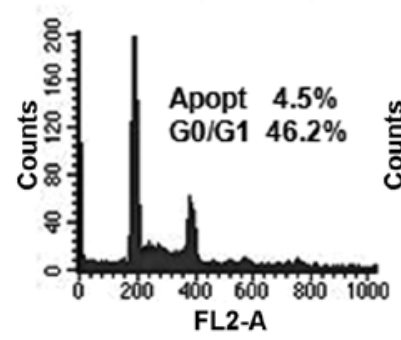

IM-9 (5-AzaC)

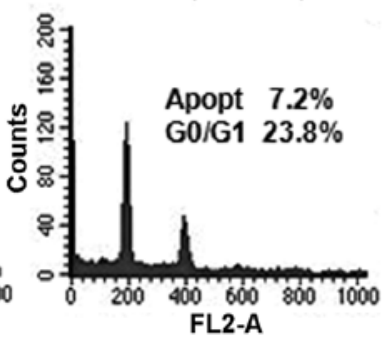

Human myeloid leukemia cells

HL-60 (Control)

HL-60 (5-AzaC)

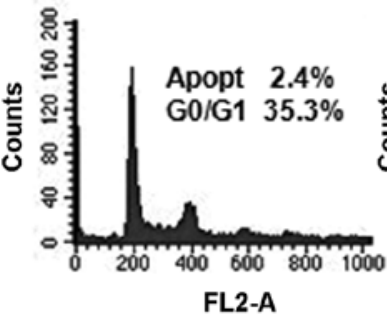

Kasumi-1 (Control)

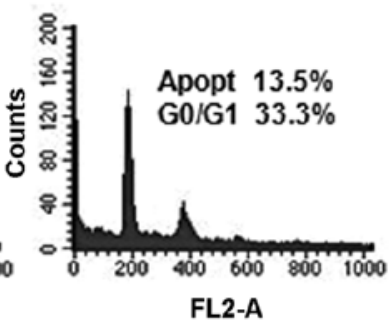

Kasumi-1 (5-AzaC)
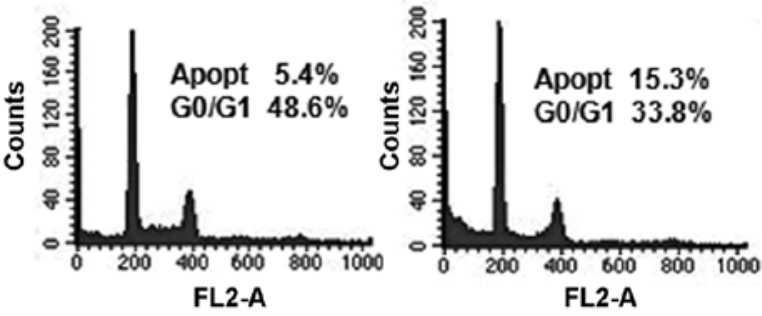

K562 (Control)

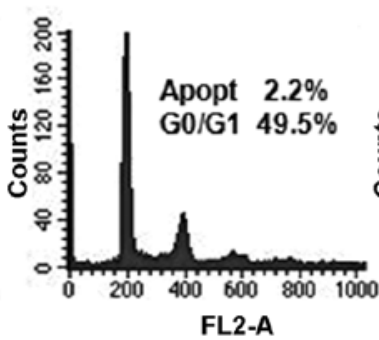

K562 (5-AzaC)

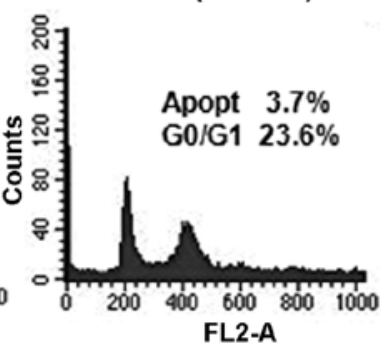

Figure 5. Effects of 5-AzaC on the cell cycle profiles of human leukemia cells. Cells were exposed to $5 \mu \mathrm{M} 5$-AzaC for 5 days, and the medium and drug were replaced every 2 days. At the end of the treatment period, the medium was removed, and the cells were fixed in $70 \%$ ethanol and washed with PBS. Cells were treated with RNAsin and stained with propidium iodide. DNA content at each cell cycle stage was analyzed by flow cytometry. The percentage of cells undergoing apoptosis and in G0/G1 phase was calculated.

suggest that low expression of the inhibin- $\alpha$ subunit gene is related to hypermethylation, mutation and $\mathrm{LOH}$.

Induction of inhibin- $\alpha$ subunit mRNA expression in the human gastric cancer cell lines by treatment with 5-AzaC demonstrates the presence of all necessary transcription factors (19). In the human leukemia cell lines analyzed in this study, expression of inhibin- $\alpha$ subunit mRNA after 5-AzaC treatment was not correlated with methylation status. In prostate cancer cell lines, expression of inhibin- $\alpha$ subunit mRNA was correlated with methylation status after treatment with 5-AzaC and trichostatin A (TSA). A reciprocal relationship between the degree of methylation and re-expression of inhibin- $\alpha$ subunit was evident after treatment with 5-AzaC. PC3 cells, which exhibited the lowest degree of methylation, were easily demethylated and expressed high levels of inhibin- $\alpha$ subunit mRNA; in contrast, LNCaP cells, which were the most highly methylated, showed lower expression of inhibin- $\alpha$ subunit mRNA (20). These results suggest that the expression level is not dependent on the degree of methylation within the promoter region.

The pattern of methylation of the inhibin- $\alpha$ gene reflected the level of the encoded protein in human leukemia cells. Immunostaining of 5-AzaC-treated-cells was performed to evaluate inhibin- $\alpha$ protein levels. Human myeloid leukemia (HL-60 and Kasumi-1) cells treated with 5-AzaC showed lower inhibin- $\alpha$ protein levels than the other cell lines. Interestingly, the increase in inhibin- $\alpha$ protein levels was greater in human lymphoid than in myeloid leukemia cells. However, the 
inhibin- $\alpha$ subunit protein level was not correlated with the methylation status of those cell lines after 5-AzaC treatment. The percentage of positively stained demethylated LNCaP and DU145 cells was lower compared with that of demethylated PC3 cells (20). Sequential gene expression changed in cancer cell lines after treatment with 5-AzaC and then focused on the genes with expression levels that changed gradually, because the effect of hypomethylation by 5 -AzaC would gradually occur. Monitoring of changes in mRNA levels after 5-AzaC treatment enables identification of genes whose expression levels changed gradually (32). 5-AzaC is a DNA demethylating and anti-cancer agent resulting in the induction of genes suppressed via DNA hypermethylation (33). Some of the genes upregulated by 5 -AzaC treatment may be transcriptionally repressed by promoter hypermethylation in gastric cancer (34). We found a correlation between inhibin- $\alpha$ mRNA and protein levels in human leukemia cells after treatment with 5-AzaC. Also, betaglycan mRNA levels were influenced by $5-\mathrm{AzaC}$ treatment. However, pattern of increases of inhibin- $\alpha$ and betaglycan mRNA showed correlation in gene expression between human lymphoid and myeloid leukemia cells.

Our data show that treatment with 5-AzaC led to a substantial increase in the doubling times of surviving leukemia cells, and an increased proportion of apoptotic cells due to nonspecific suppression of cell growth. 5-AzaC-induced growth inhibition results from the release of methylation silencing of cell cycle regulatory genes, such as p16 (35). Moreover, 5 -AzaC affects the levels of several proteins involved in cell cycle regulation, apoptosis, and survival $(36,37)$. Our results suggest that inhibin- $\alpha$ has a critical function in cells. 5-AzaC exerts a cytotoxic effect.

In this study, epigenetically mediated aberrant transcriptional silencing of the inhibin- $\alpha$ gene in human leukemia cells was characterized. The results suggested that this gene likely plays an important role in leukemia tumorigenesis as a putative tumor suppressor. Methylation of the inhibin- $\alpha$ gene promoter was evident in some human leukemia cell lines, but whether this is a cause or consequence of tumorigenesis remains to be determined. Moreover, functional studies of the inhibin- $\alpha$ gene may provide insight into the development of leukemia treatment. Our results suggest that the inhibin- $\alpha$ gene promoter is poised for activation in the cell lines tested and that the effects on transcription are primarily indirect and mediated by activation of transcription factors. Induction of the expression of other genes, either alone or in combination with inhibin- $\alpha$, may explain the observed growth suppression in human leukemia cells.

\section{References}

1. Antequera F, Boyes J and Bird A: High levels of de novo methylation and altered chromatin structure at $\mathrm{CpG}$ islands in cell lines. Cell 62: 503-514, 1990.

2. Esteller M: CpG island hypermethylation and tumor suppressor genes: A booming present, a brighter future. Oncogene 21: 5427-5440, 2002.

3. Okano M, Xie S and Li E: Cloning and characterization of a family of novel mammalian DNA (cytosine-5) methyltransferases. Nat Genet 19: 219-220, 1998

4. Jones PL, Veenstra GJ, Wade PA, Vermaak D, Kass SU, Landsberger N, Strouboulis J and Wolffe AP: Methylated DNA and $\mathrm{MeCP} 2$ recruit histone deacetylase to repress transcription. Nat Genet 19: 187-191, 1998
5. Nan $\mathrm{X}, \mathrm{Ng} \mathrm{HH}$, Johnson CA, Laherty CD, Turner BM, Eisenman RN and Bird A: Transcriptional repression by the methyl-CpG-binding protein $\mathrm{MeCP} 2$ involves a histone deacetylase complex. Nature 393: 386-389, 1998.

6. van der Ploeg LH and Flavell RA: DNA methylation in the human gamma delta beta-globin locus in erythroid and nonerythroid tissues. Cell 19: 947-958, 1980.

7. Lichtenstein M, Keini G, Cedar H and Bergman Y: B cell-specific demethylation: A novel role for the intronic $\kappa$ chain enhancer sequence. Cell 76: 913-923, 1994.

8. Lübbert M, Miller CW and Koeffler HP: Changes of DNA methylation and chromatin structure in the human myeloperoxidase gene during myeloid differentiation. Blood 78: 345-356, 1991

9. Felgner J, Kreipe H, Heidorn K, Jaquet K, Heuss R, Zschunke F, Radzun HJ and Parwaresch MR: Lineage-specific methylation of the c-fms gene in blood cells and macrophages. Leukemia 6: 420-425, 1992

10. Baylin SB, Herman JG, Graff JR, Vertino PM and Issa JP: Alterations in DNA methylation: A fundamental aspect of neoplasia. Adv Cancer Res 72: 141-196, 1998.

11. Toyooka S, Carbone M, Toyooka KO, Bocchetta M, Shivapurkar N, Minna JD and Gazdar AF: Progressive aberrant methylation of the RASSF1A gene in simian virus 40 infected human mesothelial cells. Oncogene 21: 4340-4344, 2002.

12. Tsai CN, Tsai CL, Tse KP, Chang HY and Chang YS: The EpsteinBarr virus oncogene product, latent membrane protein 1, induces the downregulation of E-cadherin gene expression via activation of DNA methyltransferases. Proc Natl Acad Sci USA 99: 10084-10089, 2002.

13. Mathews LS: Activin receptors and cellular signaling by the receptor serine kinase family. Endocr Rev 15: 310-325, 1994.

14. Mather JP, Moore A and Li RH: Activins, inhibins, and follistatins: Further thoughts on a growing family of regulators. Proc Soc Exp Biol Med 215: 209-222, 1997.

15. Risbridger GP, Schmitt JF and Robertson DM: Activins and inhibins in endocrine and other tumors. Endocr Rev 22: 836-858, 2001.

16. Matzuk MM, Finegold MJ, Su JG, Hsueh AJ and Bradley A: $\alpha$-inhibin is a tumour-suppressor gene with gonadal specificity in mice. Nature 360: 313-319, 1992.

17. Matzuk MM and Bradley A: Identification and analysis of tumor suppressor genes using transgenic mouse models. Semin Cancer Biol 5: 37-45, 1994.

18. Schmitt JF, Millar DS, Pedersen JS, Clark SL, Venter DJ, Frydenberg M, Molloy PL and Risbridger GP: Hypermethylation of the inhibin $\alpha$-subunit gene in prostate carcinoma. Mol Endocrinol 16: 213-220, 2002.

19. Kim YI, Shim J, Kim BH, Lee SJ, Lee HK, Cho C and Cho BN: Transcriptional silencing of the inhibin- $\alpha$ gene in human gastric carcinoma cells. Int J Oncol 41: 690-700, 2012.

20. Balanathan P, Ball EM, Wang H, Harris SE, Shelling AN and Risbridger GP: Epigenetic regulation of inhibin $\alpha$-subunit gene in prostate cancer cell lines. J Mol Endocrinol 32: 55-67, 2004.

21. Chatterton Z, Burke D, Emslie KR, Craig JM, Ng J, Ashley DM, Mechinaud F, Saffery R and Wong NC: Validation of DNA methylation biomarkers for diagnosis of acute lymphoblastic leukemia. Clin Chem 60: 995-1003, 2014.

22. Liu P, Shen JK, Xu J, Trahan CA, Hornicek FJ and Duan Z: Aberrant DNA methylations in chondrosarcoma. Epigenomics 8: 1519-1525, 2016.

23. Clark SJ, Harrison J, Paul CL and Frommer M: High sensitivity mapping of methylated cytosines. Nucleic Acids Res 22: 2990-2997, 1994

24. Sundblad V, Chiauzzi VA, Andreone L, Campo S, Charreau EH and Dain L: Controversial role of inhibin $\alpha$-subunit gene in the aetiology of premature ovarian failure. Hum Reprod 21: 1154-1160, 2006

25. Kuchler RJ: Development of animal cell populations in vitro. In: Biochemical Methods in Cell Culture and Virology, Kuchler RJ (ed). Dowden, Hutchinson and Ross Inc. Press, Stroudsburg, PA, pp90-113, 1977.

26. Wei QX, Claus R, Hielscher T, Mertens D, Raval A, Oakes CC, Tanner SM, de la Chapelle A, Byrd JC, Stilgenbauer S, et al: Germline allele-specific expression of DAPK1 in chronic lymphocytic leukemia. PLoS One 8: e55261, 2013.

27. Alers JC, Rochat J, Krijtenburg PJ, Hop WC, Kranse R, Rosenberg C, Tanke HJ, Schröder FH and van Dekken H: Identification of genetic markers for prostatic cancer progression. Lab Invest 80: 931-942, 2000. 
28. Suarez BK, Lin J, Burmester JK, Broman KW, Weber JL, Banerjee TK, Goddard KA, Witte JS, Elston RC and Catalona WJ: A genome screen of multiplex sibships with prostate cancer. Am J Hum Genet 66: 933-944, 2000.

29. Longui CA, Lemos-Marini SH, Figueiredo B, Mendonca BB, Castro M, Liberatore $\mathrm{R} \mathrm{Jr}$, Watanabe C, Lancellotti CL, Rocha MN, Melo MB, et al: Inhibin $\alpha$-subunit (INHA) gene and locus changes in paediatric adrenocortical tumours from TP53 R337H mutation heterozygote carriers. J Med Genet 41: 354-359, 2004.

30. Zhao J, Richter J, Wagner U, Roth B, Schraml P, Zellweger T, Ackermann D, Schmid U, Moch H, Mihatsch MJ, et al: Chromosomal imbalances in noninvasive papillary bladder neoplasms (pTa). Cancer Res 59: 4658-4661, 1999.

31. Ransom DT, Barnett TC, Bot J, de Boer B, Metcalf C, Davidson JA and Turbett GR: Loss of heterozygosity on chromosome $2 q$ Possibly a poor prognostic factor in head and neck cancer. Head Neck 20: 404-410, 1998.

32. Arai M, Yokosuka O, Hirasawa Y, Fukai K, Chiba T, Imazeki F, Kanda T, Yatomi M, Takiguchi Y, Seki N, et al: Sequential gene expression changes in cancer cell lines after treatment with the demethylation agent 5-Aza-2'-deoxycytidine. Cancer 106: 2514-2525, 2006.
33. Sayar N, Karahan G, Konu O, Bozkurt B, Bozdogan O and Yulug IG: Transgelin gene is frequently downregulated by promoter DNA hypermethylation in breast cancer. Clin Epigenetics 7: 104, 2015.

34. Mikata R, Yokosuka O, Fukai K, Imazeki F, Arai M, Tada M, Kurihara T, Zhang K, Kanda T and Saisho H: Analysis of genes upregulated by the demethylating agent 5 -aza-2'-deoxycytidine in gastric cancer cell lines. Int J Cancer 119: 1616-1622, 2006.

35. Bender CM, Pao MM and Jones PA: Inhibition of DNA methylation by 5-aza-2'-deoxycytidine suppresses the growth of human tumor cell lines. Cancer Res 58: 95-101, 1998.

36. Song SH, Jong HS, Choi HH, Inoue H, Tanabe T, Kim NK and Bang YJ: Transcriptional silencing of Cyclooxygenase-2 by hyper-methylation of the $5^{\prime} \mathrm{CpG}$ island in human gastric carcinoma cells. Cancer Res 61: 4628-4635, 2001.

37. Valdez BC, Li Y, Murray D, Corn P, Champlin RE and Andersson BS: 5-Aza-2'-deoxycytidine sensitizes busulfanresistant myeloid leukemia cells by regulating expression of genes involved in cell cycle checkpoint and apoptosis. Leuk Res 34: $364-372,2010$ 